\title{
Hematopoietic stem cell transplantation from an infected SARS- CoV2 donor sibling
}

\author{
Usanarat Anurathapan ${ }^{1}$ - Nopporn Apiwattanakul ${ }^{1}$ Samart Pakakasama ${ }^{1} \cdot$ Pongpak Pongphitcha $^{1}$. \\ Arunee Thitithanyanont ${ }^{2} \cdot$ Ekawat Pasomsub $^{3} \cdot$ Suradej Hongeng $\mathbb{B}^{1}$
}

Received: 10 May 2020 / Revised: 20 May 2020 / Accepted: 3 June 2020 / Published online: 11 June 2020

(c) Springer Nature Limited 2020

\section{To the Editor:}

COVID-19 pandemic is a global health threat with high fatality rate especially in the elderly and the immunocompromised. Current knowledge about its prevalence, spreading capability, and clinical patterns is still limited, resulting in difficulty in surveillance and management strategy [1, 2]. Patients undergoing hematopoietic stem cell transplantation (HSCT) are a group of patients with special immunocompromised situation and could have potentially devastating outcome if get sick with COVID-19. Since there are 90,000 HSCT carried out annually worldwide, it is possible that this might be the case [3].

We report a case of 7-year-old female diagnosed with beta-thalassemia hemoglobin $\mathrm{E}$ who receives regular transfusion with filtered packed red blood cell since 1 year of age. She was admitted for HLA-matched sibling HSCT on April 7, 2020. Conditioning regimen consisted of iv. busulfan $130 \mathrm{mg} / \mathrm{m}^{2} /$ day $\times 4$ days (day -9 to day -6 ) and iv. cyclophosphamide $50 \mathrm{mg} / \mathrm{kg} /$ day (day -5 to day -2 ) [4] was given and transplantation day (D0) was planned to be on April 17, 2020. The patient and her mother who stayed with her wore appropriate personal protective equipment during their stay in pre-transplantation period. They did not experience any fever or respiratory symptoms.

The donor, her younger brother, was admitted one day before planned D0 and had nasopharyngeal swabbed for

Suradej Hongeng

suradej.hon@mahidol.ac.th

1 Department of Pediatrics, Faculty of Medicine Ramathibodi Hospital, Mahidol University, Bangkok, Thailand

2 Department of Microbiology, Faculty of Science, Mahidol University, Bangkok, Thailand

3 Department of Pathology, Faculty of Medicine Ramathibodi Hospital, Mahidol University, Bangkok, Thailand
SARS-CoV2. This pre-operative swab is done routinely in every patient planned for anesthesia according to the hospital policy. Swab result was positive for SARS-CoV2 and was confirmed by another test done $7 \mathrm{~h}$ later. Despite the swab result he was doing well without fever or any other symptoms. We decided to go on with transplantation since the patient would have a slim chance of survival if she does not receive donor stem cells. Surveillance swab for the family were done and positive results were also found in the patient's aunt and mother who closely took care of the patient.

Bone marrow harvest was carried out under general anesthesia in the operating room using airborne infection isolation routine. Pre-operative medication consisted of one dose of favipiravir, hydroxychloroquine, and darunavir/ritonavir. All involved medical staffs wore enhanced personal protection equipment. Bone marrow with stem cells at a dose of $4.94 \times 10^{6} \mathrm{CD} 34+$ cells $/ \mathrm{kg}$ was harvested, processed and given to the patient on the same day. This harvested marrow was tested negative for SARS-CoV2 by RT-PCR.

The patient stayed in airborne infection isolation unit after transplantation. Her GVHD prophylaxis consisted of iv cyclosporine at a dose of $3 \mathrm{mg} / \mathrm{kg} /$ day starting on day-3 together with short course methotrexate $5 \mathrm{mg} / \mathrm{m}^{2}$ on day $+1,+3,+6$, and +11 [4]. The infection prophylaxis medicines were penicillin, ciprofloxacin, and micafungin. Her transplantation was uneventful. Neutrophil engraftment occurred on day +13 . The peripheral blood nucleated cell chimerism showed $100 \%$ of donor cells on day +20 . We subsequently tested RT-PCR SARS-CoV2 in nasopharyngeal swab and blood together with serology tests in the blood from patient, donor, mother, and aunt as shown in Table 1. She was transferred back to the BMT unit after 14 days of negative results from all tests. Since all of three COVID-19 patients did not have seroconversion, it is possible that all patients were asymptomatic and might have low viral load, which would not elicit antibody response. Infected patients without seroconversion have been reported [5]. 
Table 1 The results of RT-PCR of nasopharyngeal swabs and antibody to SARS-CoV2 from patient, donor, mother and aunt.

\begin{tabular}{|c|c|c|c|c|c|c|c|c|c|c|}
\hline Day of transplant & $\begin{array}{l}4 / 16 \\
-1\end{array}$ & $\begin{array}{l}4 / 17^{\mathrm{a}} \\
0\end{array}$ & $\begin{array}{l}4 / 18 \\
1\end{array}$ & $\begin{array}{l}4 / 19 \\
2\end{array}$ & $\begin{array}{l}4 / 20 \\
3\end{array}$ & $\begin{array}{l}4 / 21 \\
4\end{array}$ & $\begin{array}{l}4 / 22 \\
5\end{array}$ & $\begin{array}{l}4 / 24 \\
7\end{array}$ & $\begin{array}{l}4 / 27 \\
10\end{array}$ & $\begin{array}{l}5 / 1 \\
14\end{array}$ \\
\hline Donor RT-PCR IgM IgG & pos & $\begin{array}{l}0.00 \\
0.05\end{array}$ & & & neg & & & & & $\begin{array}{l}0.00 \\
0.02\end{array}$ \\
\hline Recipient RT-PCR IgM IgG & neg & & $\begin{array}{l}\text { neg } \\
0.47 \\
0.07\end{array}$ & neg & neg & neg & neg & neg & neg & $\begin{array}{l}\text { neg } \\
0.26 \\
0.04\end{array}$ \\
\hline Mother RT-PCR IgM IgG & pos & & neg & & neg & & & & & $\begin{array}{l}0.53 \\
0.06\end{array}$ \\
\hline Aunt RT-PCR IgM IgG & pos & & neg & & neg & & & & & $\begin{array}{l}0.05 \\
0.06\end{array}$ \\
\hline
\end{tabular}

IgM and IgG were performed by MAGLUMI ${ }^{\mathrm{TM}}$ 2019-nCoV IgM (CLIA) and MAGLUMI ${ }^{\mathrm{TM}}$ 2019-nCoV IgG (CLIA), respectively. Cut-off value of positivity is $0.69 \mathrm{AU} / \mathrm{mL}$ for both IgG and IgM.

neg negative, pos positive.

${ }^{a}$ Day of stem cell infusion (day 0).
Current EBMT recommendations do not recommend stem cell donation when donor is COVID-19 positive [6]. This report illustrates that transplantation from COVID-19 donors is feasible and viral transmission through stem cell transplantation did not happen since the stem cells product is RT-PCR negative for SARS-CoV2. However, donor care in the COVID-19 era should be revisited. Necessary measures are needed to ensure that the donor is healthy and free of any disease, including COVID-19, at the time of transplantation. This would ensure the safety of medical personnels who closely take care of donors. In addition, whether harvested marrow could transmit SARS-CoV2 is still unknown. A report from Singapore demonstrated that the virus could be found in blood about $8 \%$ of infected patients [7]. This possibly poses risk of transmission of the virus via the graft from a donor to a recipient.

Acknowledgements We would like to thank the Ramathibodi Foundation.

\section{Compliance with ethical standards}

Conflict of interest The authors declare that they have no conflict of interest.

Publisher's note Springer Nature remains neutral with regard to jurisdictional claims in published maps and institutional affiliations.

\section{References}

1. Guan WJ, Ni ZY, Hu Y, Liang WH, Ou CQ, He JX, et al. Clinical characteristics of coronavirus disease 2019 in China. N Engl J Med. 2020;382:1708-20.

2. Richardson S, Hirsch JS, Narasimhan M, Crawford JM, McGinn T, Davidson KW, et al. Presenting characteristics, comorbidities, and outcomes among 5700 patients hospitalized with COVID-19 in the New York City area. JAMA. 2020;323:2052-5.

3. Niederwieser D, Baldomero H, Atsuta Y, Aljurf M, Seber A, Greinix HT, et al. One and half million hematopoietic stem cell transplants (HSCT). Dissemination, trends and potential to improve activity by telemedicine from the Worldwide Network for Blood and Marrow Transplantation (WBMT). Blood. 2019:134 Suppl 1.

4. Hongeng S, Pakakasama S, Chuansumrit A, Sirachainan N, Kitpoka $\mathrm{P}$, Udomsubpayakul $\mathrm{U}$, et al. Outcomes of transplantation with related- and unrelated-donor stem cells in children with severe thalassemia. Biol Blood Marrow Transpl. 2006;12:683-7.

5. Long QX, Liu BZ, Deng HJ, Wu GC, Deng K, Chen YK, et al. Antibody responses to SARS-CoV-2 in patients with COVID-19. Nat Med. 2020. https://doi.org/10.1038/s41591-020-0897-1

6. Ljungman P, Mikulska M, de la Camara R, Basak GW, Chabannon $\mathrm{C}$, Corbacioglu S, et al. The challenge of COVID-19 and hematopoietic cell transplantation; EBMT recommendations for management of hematopoietic cell transplant recipients, their donors, and patients undergoing CAR T-cell therapy. Bone Marrow Transpl. 2020;13:1-6.

7. Young BE, Ong SWX, Kalimuddin S, Low JG, Tan SY, Lo J, et al. Epidemiologic features and clinical course of patiemts infeted with SARS-CoV-2 in Singapore. JAMA 2020;323:1488-94. 